\title{
CRYPTOSPORIDIOSIS IN PEDIATRIC PATIENTS
}

\author{
Nélida SAREDI (1) \& Javier BAVA (1)
}

\section{SUMMARY}

Cryptosporidium was detected in $21(3.8 \%)$ individual stool samples collected from 553 pediatric patients hospitalized in our center employing a Telemann concentration technique (formalin-ether-centrifugation) and stained with the modified Kinyoun method.

The mean age of populations with Cryptosporidiosis (16 boys and 5 girls) was 11 months; 15 months for girls and 6.5 for boys. Ages of $81 \%$ of them were less than 19 months.

Seventy-six per cent of patients lived on the outskirts of Buenos Aires and $71 \%$ lacked pretreated running water at home. In $62 \%$ of the cases parasitological diagnoses coincided with warm seasons.

At diagnosis mucous $(63 \%)$ or watery $(36 \%)$ diarrhea was presented in $90 \%$ of the patients with a median of $5(3-8)$ bowel movements per day. Fever was presented in $66 \%$ of patients while abdominal pain and vomits in $60 \%$ and $52 \%$, respectively. The median time from hospitalization up to parasitologic diagnosis was 20 days. Concomitant diseases observed were malnutrition, acute leukemia, bronchiolitis, HIV infection, anemia, celiac disease, myelofibrosis, vitelline sac tumor, neutropenia, osteosarcoma and dehydration.

Cryptosporidiosis in our environment seems to occur more frequently in children younger than 18 months of age; who present diarrhea; are immunodeficient; come from a low socioeconomical background; and who live in poor sanitary conditions with no potable running water.

KEYWORDS: Cryptosporidium parvum; Cryptosporidiosis; Cryptosporidiosis in children.

\section{INTRODUCTION}

Cryptosporidiosis is a widespread, zoonotic disease produced by coccidial protozoa: Cryptosporidium parvum. It localizes on the intestinal cells and causes acute or chronic, self limited diarrhea in immunocompetent host and severe and prolonged diarrhea in immunocompromised people, fundamentally AIDS patients ${ }^{1,4,14}$. Diagnosis is achieved by microscopic examination of feces. Oocysts of Cryptosporidium are observed with the Kinyoun stain or similar or immunofluorescence with monoclonal antibodies ${ }^{10,12,14}$. The aim of this paper is to rebound the importance of Cryptosporidiosis as etiological agent of intestinal infections in children with, different concomitant diseases and to presents their epidemiological, clinical and parasitological characteristics in hospitalized children in the "Ricardo Gutiérrez" Children's Hospital in Buenos Aires.

\section{MATERIALS AND METHODS}

Patients: all patients hospitalized between September 1992 and July 1995, with a clinical feature suggestive of Cryptosporidiosis and parasitological available results of stool sample studies where included.

Diagnosis of Cryptosporidiosis: was achieved by microscopic visualization (modified Kenyan stain) of Cryptosporidium oocysts in at least one stool sample, processed by modified Telemann concentration technique (formalin-ether-centrifugation) ${ }^{7,12}$.

Analyses of the data: a base data for each patient was created which including age; sex; place of residence; concomitant disease; presence of diarrhea; vomiting; fever and abdominal pain; history of other parasitic infections; characteristics of the bowel movement (number per day, consistency, color, presence of blood), potable water, date of hospitalization and diagnoses of Cryptosporidiosis.

Statistics: the age of girls and boys with Cryptosporidiosis were analyzed employing the Mann Whitney rank sum test and the prevalence of Cryptosporidiosis by sexes and during OctoberMarch and April-September periods was analyzed using the Contingency tables (chi square). All calculations were done with the Start Primer program and $p$ values of $<0.05$ were considered significant.

(1) Laboratorio de Parasitologia. Hospital de Niños "Ricardo Gutierrez". Gallo 1330. CP. Buenos Aires. Argentina.

(2) Sección Parasitologia. Hospital de Infecciosas "Francisco J. Muñis". Buenos Aires. Argentina.

Correspondence to: Dr. Nélida Saredi. Mariscal Solano López 2320. 1429 Buenos Aires, Argentina 


\section{RESULTS}

Epidemiological, clinical and parasitological data obtained from 21 patients (16[76.19\%] boys and 5 [23.80\%] girls) with cryptosporidiosis diagnosed in this study are summarized in the table 1. During the period September 1992 to July 1995, Cryptosporidium was detected in 21 (3.8\%) individual stool samples taken from 553 patients (285 boys[51.53\%] and 268 girls [49.46\%] ) hospitalized in our center. The higher prevalence of cryptosporidiosis in boys was statistically significant. The median age of patients with cryptosporidiosis was 11 (1-113) months; 15 (14-87) for girls and 6.5 (1-113) months for boys (difference not significant). At diagnoses, 17 of them $(80.95 \%)$ were $\leq 18$ months. Sixteen $(76.19 \%)$ patients lived on the outskirts of Buenos Aires, 2 (9.52\%) in cities of the province of Buenos Aires and the remaining 3 (14.28\%) in other provinces of Argentina. Only 6 (28.57\%) of the 21 patients had potable running water in their houses.

Among 553 parasitologic studies, 254 were done on the period April-September and 299 during the October-March one. Parasitological diagnoses coincided with warm months in Argentina (October to March) $13(61.90 \%)$ and with autumn and winter (April to September) in $8(38.10 \%)$ cases (difference no significative).

At diagnoses, 19 (90.47\%) patients had diarrhea, with a median of 5 (3-8) bowel movements per day. In $12,63.15 \%$ cases the feces had mucous ( 4 with blood striae) while in $7(36.84 \%$ ) cases the feces were watery. The color of the stools was greenish in $9(52.94 \%)$ cases and yellowish in other $8(47.05 \%)$ cases. The most frequent symptoms present at diagnoses were fever $(66.66 \%)$, vomits $(52.38 \%)$ and abdominal pain $(57.14 \%)$. The median time for hospitalization to parasitological diagnoses was 20 (1-50) days.

Parasitological stool examination was negative for other enteroparasites, although 5 (23.80\%) patients had previously histories of intestinal parasitosis: Giardia lamblia in 2 cases, Trichomonas hominis, Ascaris lumbricoidis and Entamoeba histolytica in one case each. These 5 patients' houses lacked potable water. Fecal samples were negative for Rotavirus in 9 patients with cryptosporidiosis in which this determination was realized. Salmonella enteritidis and Shigella sp. were isolated in $2(9.52 \%)$ out of 21 cases.

Concomitant disease found in the population under study were malnutrition ( 5 patients), acute leukemia ( 3 cases), bronchiolitic syndrome (2 cases), HIV infection (2 cases) and anemia, celiac disease, myelofibrosis, vitelline sac tumor, neutropenia, osteosarcoma and dehydration (one case each).

\section{DISCUSSION AND CONCLUSIONS}

Cryptosporidium has been confirmed as an emerging pathogen in immunocompetent and immunocompromised children hospitalized with diarrhea. The most frequent symptoms seen at diagnosis concurred with other reports on infantile Cryptosporidiosis ${ }^{2,3,6,8,13}$.

The presence of Cryptosporidium in stool samples was an important clue to HIV infection and subsequent serological diagnosis in two patients. Parasitological diagnosis was retarded in many cases because Cryptosporidiosis was not consistently a primary clinical suspicion on admission and this tended to lengthen the median time of diagnosis.

As observed in other studies, carried out in different sites of the world, various factors can influence the reported prevalence of Cryptosporidium: a) methodology of stool sample collection (number and quality); b) techniques employed in the microscopic identification, (acid-fast stains or immunofluorescence with monoclonal antibodies); c) presence of any immunodeficiency or predisposing clinical condition; d) degree of development of each country and e) socioeconomical characteristics of the different

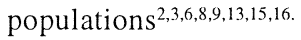

Cryptosporidiosis is a widespread parasitic disease occurring in urban and rural areas. The universal prevalence of Cryptosporidiosis is approximately $4-10 \%$. Cryptosporidium is observed in $1-4 \%$ of the general population in the United States and Europe. In undeveloped countries, these figures are higher (3-20\%). In Argentina, official information concerning the prevalence of Cryptosporidium in AIDS patients is partial, but is estimated to be around $5 \%{ }^{1,4,5,10}$.

Most patients lived on the outskirts of Buenos Aires with poor sanitary conditions. The waterborne cases could be attributed to the fact that $75 \%$ of the patients lived in houses without potable running water.

Cryptosporidiosis must be considered as a part of the differential diagnosis among children hospitalized with diarrhea, independently of their immunologic status. According to the results of the present study, Cryptosporidiosis in our environment seems to occur more frequently in children (a) younger than 18 months of age; (b) who present diarrhea; (c) are immunodeficient; (d) come from a low socioeconomical background; and (e) who live in poor sanitary conditions with no potable running water.

Approximately 10 million of people live on the outskirts of Buenos Aires where sanitary conditions and water treatment procedures to produce potable drinking water are not optimal. For these reasons Cryptosporidiosis must be considered as a serious public health problem now and in the future.

\section{RESUMO}

\section{Criptosporidiose em pacientes pediátricos}

Cryptosporidium foi detectado em $21(3,8 \%)$ amostras de fezes obtidas de 553 pacientes pediátricos atendidos em nosso centro médico, com a técnica de concentração de Telemann (formalina-éter-centrifugação) e coloração de Kinyoun modificada.

A média etária da população com criptosporidiose (16 meninos e 5 meninas) foi de 11 meses: 15 para as meninas e 6,5 meses para os meninos; $81 \%$ das idades desses pacientes foram menores de 19 meses; $76 \%$ eram moradores nas zonas marginais de Buenos Aires e $71 \%$ com falta de água potável. 
SAREDI, N. \& BAVA, J. - Cryptosporidiosis in pediatric patients. Rev. Inst. Med. trop. S. Paulo, 40 (3): 197-200, 1998.

TABLE 1

Epidemiological, Clinical and Parasitological Features of 21 Patients With Cryptosporidiosis Hospitalized in the "Ricardo Gutierrez" Children's Hospital of Buenos Aires (July 1992-November 1995).

\begin{tabular}{|c|c|c|c|c|c|c|c|c|c|c|}
\hline \multirow[t]{2}{*}{$\mathrm{Pt}$} & \multirow{2}{*}{$\begin{array}{l}\text { Age } \\
(1)\end{array}$} & \multirow[t]{2}{*}{ Sex } & \multirow[t]{2}{*}{ Residence } & \multirow{2}{*}{$\begin{array}{c}\text { Running } \\
\text { drinking } \\
\text { water }\end{array}$} & \multirow{2}{*}{$\begin{array}{l}\text { Previous } \\
\text { parasitic } \\
\text { infections }\end{array}$} & \multirow{2}{*}{$\begin{array}{c}\text { Concomitant } \\
\text { disease at } \\
\text { diagnosis }\end{array}$} & \multicolumn{4}{|c|}{ Gastrointestinal Symptoms } \\
\hline & & & & & & & Fever & Vomit & $\begin{array}{l}\text { Abdominal } \\
\text { Pain }\end{array}$ & Diarrhea \\
\hline 1 & 87 & $\mathrm{~F}$ & $\mathrm{BAO}$ & YES & NO & ALL & YES & YES & YES & YES \\
\hline 2 & 113 & $\mathrm{M}$ & $\mathrm{BAO}$ & YES & NO & ALM & YES & YES & YES & YES \\
\hline 3 & 18 & $\mathrm{M}$ & $\mathrm{BAO}$ & NO & NO & $\begin{array}{c}\text { Malnutrition } \\
\text { and anemia }\end{array}$ & YES & NO & NO & YES \\
\hline 4 & 6 & M & $\mathrm{BAO}$ & NO & $\begin{array}{l}\text { Giardia } \\
\text { lamblia }\end{array}$ & Malnutrition & YES & NO & NO & YES \\
\hline 5 & 1 & M & BAP & NO & NO & $\begin{array}{l}\text { Bronchiolitic } \\
\text { syndrome }\end{array}$ & NO & $\mathrm{NO}$ & NO & NO \\
\hline 6 & 2 & M & $\mathrm{BAO}$ & YES & NO & HIV (+) & YES & NO & NO & YES \\
\hline 7 & 14 & $\mathrm{~F}$ & $\mathrm{BAO}$ & NO & $\begin{array}{c}\text { Ascaris } \\
\text { lumbricoides }\end{array}$ & NR & YES & YES & YES & YES \\
\hline 8 & 18 & $\mathrm{~F}$ & Corrientes & YES & NO & Celiac disease & YES & NO & YES & YES \\
\hline 9 & 12 & M & Formosa & $\mathrm{NO}$ & $\mathrm{NO}$ & Myelofibrosis & NO & NO & NO & NO \\
\hline 10 & 6 & M & $\mathrm{BAO}$ & NO & NO & NR & YES & NO & YES & YES \\
\hline 11 & 31 & M & Misiones & NO & $\begin{array}{l}\text { Giardia } \\
\text { lamblia }\end{array}$ & $\begin{array}{l}\text { Vitelline sac } \\
\text { tumor }\end{array}$ & $\mathrm{NO}$ & YES & NO & YES \\
\hline 12 & 5 & M & BAP & NO & NO & NR & NO & YES & YES & YES \\
\hline 13 & 2 & M & $\mathrm{BAO}$ & YES & NO & HIV (+) & YES & YES & YES & YES \\
\hline 14 & 51 & M & $\mathrm{BAO}$ & NO & NO & $\begin{array}{l}\text { Neutropenia and } \\
\text { osteosarcoma }\end{array}$ & YES & YES & YES & YES \\
\hline 15 & 1 & M & $\mathrm{BAO}$ & NO & NO & Malnutrition & YES & YES & NO & YES \\
\hline 16 & 8 & M & $\mathrm{BAO}$ & NO & $\begin{array}{l}\text { Entamoeba } \\
\text { histolytica }\end{array}$ & Malnutrition & NO & $\mathrm{NO}$ & YES & YES \\
\hline 17 & 7 & M & $\mathrm{BAO}$ & NO & NO & Dehydratation & YES & YES & YES & YES \\
\hline 18 & 15 & $\mathrm{~F}$ & $\mathrm{BAO}$ & YES & NO & ALL & YES & NO & YES & YES \\
\hline 19 & 14 & $\mathrm{~F}$ & $\mathrm{BAO}$ & NO & NO & Malnutrition & YES & NO & NO & YES \\
\hline 20 & 11 & M & $\mathrm{BAO}$ & NO & $\begin{array}{l}\text { Trichomonas } \\
\text { hominis }\end{array}$ & NR & YES & YES & YES & YES \\
\hline 21 & 5 & M & $\mathrm{BAO}$ & NO & NO & $\begin{array}{l}\text { Bronchiolitic } \\
\text { syndrome }\end{array}$ & NO & NO & NO & NO \\
\hline
\end{tabular}

Pt: Patient; M: male; F: female: BAP: Buenos Aires Province; BAO: Buenos Aires outskirts; NR: no registered; $\quad$ ALL: acute lymphatic leukemia; ALM: acute myeloid leukemia. (1): in months. 
Em $62 \%$ dos casos os diagnósticos parasitológicos foram efetuados nas estações com alta temperatura.

No momento do diagnóstico observou-se diarréia em $90 \%$ dos pacientes. Entre estes $63 \%$ apresentavam diarréia com presença de muco e $36 \%$ diarréia aquosa, com média de 5 evacuações diárias. Febre foi notada em $66 \%$ dos pacientes e dores abdominais e vômitos em $60 \%$ e $52 \%$, respectivamente. O tempo médio de internação, desde o diagnóstico parasitológico, foi de 20 dias.

As doenças concomitantes observadas foram desnutrição, leucemia aguda, bronquiolite, infecções por HIV, anemia, doença celíaca, mielofibrose, tumor de saco vitelino, neutropenia, osteossarcoma e desidratação.

A criptosporidiose no nosso meio parece ocorrer em crianças menores de 18 meses de idade; as que apresentam diarréia, são imunodeficientes e pertencem a faixas sócioeconômicas de baixo nível, como moradores de zonas com precárias condições sanitárias desprovidas de água potável.

\section{ACKNOWLEDGMENT}

We are indebted to Dr. Kathy Miller Corbera for your assistance in this paper.

\section{REFERENCES}

1. BLACKMAN, E.; BINDER, S.; GAULTIER, C. et al. - Cryptosporidiosis in HIV-infected patients: diagnostic sensitivity of stool examination, based on number of specimens submitted. Amer. J. Gastroent., 92: 451-453, 1997.

2. BRANDONISIO, O.; MARANGI, A.; PANARO, M.A. et al. - Prevalence of Cryptosporidium in children with enteritis in southern Italy. Europ. J. Epidem., 12: 187-190, 1996.

3. CLAVEL, A.; OLIVARES, J.L.; FLETA, J. et al. - Seasonality of cryptosporidiosis in children. Europ. J. clin. Microbiol. infect. Dis., 15: 77-79, 1996.

4. CRIPTOSPORIDIOSIS. In: BENENSON, A.S., ed. El control de las enfermedades transmisibles en el hombre. 15. ed. Washington, Organización Panamericana de la Salud, 1992. p. 75-78. (Publicación Científica No. 538).
5. EL SIDA en la Argentina. Período 1982-1993. Buenos Aires, Programa Nacional de Lucha contra el SIDA/Ministerio de Salud y Accion Social. p. 18.

6. ENRIQUEZ, F.J.; AVILA, C.R.; SANTOS, J.I. et al. - Cryptosporidium infections in Mexican children: clinical, nutritional, enteropathogenic and diagnostic evaluations. Amer. J. trop. Med. Hyg., 56: 254-257, 1997.

7. FELDMAN, R.E. \& GUARDIS, M. del V. - Diagnóstico parasitológico. In: BASUALDO, J.A.; COTO, C.E. \& DE TORRES, R.A. Microbiologia biomédica. Buenos Aires, Editorial Atlante SRL, 1996. p. 1109-1118.

8. FRANCO, R.M.B. \& CORDEIRO, N. da S. - Giardiose e criptosporidiose em creches no município de Campinas, SP. Rev. Soc. bras. Med. trop., 29: 585-591, 1996.

9. GENTILE, G.; VENDITTI, M.; MICOZZI, A. et al. - Cryptosporidiosis in patients with hematologic malignancies. Rev. infect. Dis., 13: 842-846, 1991.

10. GUARDIS, M. del V. - Criptosporidiosis. In: BASUALDO, J.A.; COTO, C.E. \& DE TORRES, R.A. Microbiologia biomédica. Buenos Aires, Editorial Atlante SRL, 1996. p. 943 -947.

11. GUERRANT, R.L. - Cryptosporidiosis: an emerging, highly infectious threat. Emerg. infect. Dis., 3: 51-57, 1997.

12. HENDRICKSON, D.A. \& KRENZ, H.M. - Reagents and stains. In: BALLOWS, A.; HUSLER, W.J.; HERMANN, K.L.; ISEMBERG, H.D. \& SHADOMY, H.J. Manual of clinica1 microbiology. 5. ed. Washington, American Society for Microbiology, 1991. p. 1289-1314.

13. LEDERER, W.; AllerberGER, F. \& DIERICH, M.P. - Cryptosporidia associated gastroenteritis; epidemiologic study of children in Tyrol and Voralberg: Wien. klin. Wschr., 108: 649-653, 1996.

14. MARShALL, M.M.; NAUMOVITZ, D.; ORTEGA, Y. et a1. - Waterbone protozoan pathogens. Clin. Microbiol. Rev., 10: 67-85, 1997.

15. RODRIGUEZ HERNÁNDEZ, J.; CANUT-BLASCO, A. \& MARTINSÁNCHEZ, A.M. - Seasonal prevalence of Cryptosporidium and Giardia infections in children attending day care centers in Salamanca (Spain) studied for a period of 15 months. Europ. J. Epidem., 12: 291-295, 1996.

16. SREDDHARAN, A.; JAYSHREE, R.S. \& SRIDHAR, H. - Cryptosporidiosis among cancer patients: an observation. J. Diarrhoeal Dis. Res., 14: 211 213, 1996.

Received: 29 December 1997

Accepted: 11 May 1998 